\title{
sciendo
}

\section{ASSESSMENT OF GUT MICROBIOTA AND SELECTED BLOOD PARAMETERS IN WEANED PIGLETS FOLLOWING SUPPLEMENTATION WITH A PROBIOTIC AND VITAMIN C}

\author{
Leszek Tymczyna ${ }^{1}$, Beata Trawińska ${ }^{1}$, Marta Kowaleczko ${ }^{1}$, Anna Chmielowiec-Korzeniowska ${ }^{1 *}$, \\ Jerzy Lechowski \\ ${ }^{1}$ Department of Animal Hygiene and Environmental Hazards, University of Life Sciences, \\ Akademicka 13, 20-950 Lublin, Poland \\ ${ }^{2}$ Department of Biochemistry and Toxicology, University of Life Sciences, Akademicka 13, \\ 20-950 Lublin, Poland \\ •Corresponding author: anna.korzeniowska@up.lublin.pl
}

\begin{abstract}
The aim of the study was to assess the gut microbiota and selected haematological and biochemical blood parameters of weaned piglets following dietary supplementation with a probiotic and vitamin $\mathbf{C}$. The piglets were divided into a control group (group C) and an experimental group (group E), with 30 piglets in each group. All animals received the same feed ad libitum. The animals in the control group (group $C$ ) received feed with no added probiotic and vitamin $C$. The piglets in the experimental group (group $\mathbf{E}$ ) were given a supplement containing a probiotic (Bacillus cereus $1 \times 10^{9}$ $\mathrm{CFU} / \mathrm{kg}$ ) in the amount of $1.5 \mathrm{~g} / \mathrm{piglet} /$ day and vitamin $C$ in the amount of $300 \mathrm{mg} / \mathrm{piglet} / \mathrm{day}$. The supplement was administered for 28 days. The total numbers of bacteria of the family Enterobacteriaceae and of the genus Lactobacillus were determined in faeces. The erythrocyte count, haemoglobin level, haematocrit, leukocyte count, and percentages of neutrophils and lymphocytes were determined in the blood. The biochemical analysis concerned the concentration of triacylglycerols, total cholesterol, and LDL and HDL cholesterol. In group $\mathrm{E}$ a significant decrease $(\mathrm{P}<0.01)$ in the total number of Enterobacteriaceae bacteria was observed in the faeces of the piglets, accompanied by an increase in the number of lactobacilli relative to group $C$. $E$. coli was found to predominate over other microorganisms. Salmonella choleraesuis bacteria were present in the faeces of both groups before administration of the supplement, but were not found after its use. The supplement with probiotic and vitamin $\mathrm{C}$ caused a significant increase in the erythrocyte, haemoglobin and haematocrit levels in the blood of the piglets and a significant decrease in the concentration of triacylglycerols, total cholesterol and LDL cholesterol.
\end{abstract}

Key words: blood, gut microbiota, piglets, probiotic, vitamin C

Weaning of piglets and the switch to solid food are highly stressful for these young animals. The greatest problem during this period is diarrhoea of complex aetiology, in which besides the infectious agents (enterotoxic strains of Escherichia coli, 
rotaviruses and coronaviruses), environmental and nutritional factors play the most important role. The simultaneous change in diet and housing conditions leads to a quantitative and qualitative imbalance of the gut microbiota, and even to the multiplication of pathogenic bacteria. To prevent gastrointestinal disorders in young pigs, the use of probiotics, to which numerous health benefits are ascribed, is becoming increasingly common.

Probiotics exert a beneficial effect on the intestinal microbiota. They are used to protect the intestinal wall against colonization by pathogenic bacteria (e.g. Salmonella spp. and E. coli) and to increase the number of normal gut microflora (Asml et al., 2015; Corcionivoschi et al., 2010; Shengfa and Nyachoti, 2017). Furthermore, the levorotatory lactic acid in probiotic products reduces the absorption of toxic substances such as ammonia into the blood (Mojka, 2014). Among the mechanisms of action of probiotic bacteria, substances they produce that prevent the development of pathogenic microbes play an important role. These include organic acids, hydrogen peroxide and bacteriocins (Śliżewska et al., 2006). Administration of probiotics containing strains of the genus Bacillus or Lactobacillus to weaned piglets reduces mortality and the incidence of conditions with diarrhoeal symptoms (Asml et al., 2015; Dalmini et al., 2017; Giang et al., 2012). In addition, probiotic substances form a barrier against pathogenic microbes by adhering to the intestinal epithelium, thus increasing the body's resistance. Probiotics also stimulate the immune system by increasing immunoglobulin production, enhancing macrophage and lymphocyte activity, and stimulating production of $\gamma$-interferon (Śliżewska et al., 2006).

In livestock farming, strains of probiotic bacteria, including lactic acid bacteria of the genus Lactobacillus, bacteria of the genera Bifidobacterium and Enterococcus, yeast Saccharomyces spp., and spore-forming bacteria, including Bacillus spp., can be enriched with elements (mainly Fe), colostral immunoglobulins, and vitamins (Janik et al., 2006). Research conducted by Kunavue and Lien (2012) and by Liu et al. (2018) has also shown that the addition of organic acids, such as fulvic acid, or xylooligosaccharides may enhance their health-promoting activity. Lee et al. (2014) have demonstrated that the addition of natural acidifiers derived from the fermentation of citrus fruit juices can also stimulate the growth of probiotic strains.

In our study, a probiotic was used in combination with ascorbic acid (vitamin $\mathrm{C}$ ) as a feed additive. We posited that this combination would have a beneficial effect on the gut microbiota of weaned piglets and on their haematological and biochemical parameters.

Vitamin C, among other vitamins, plays an important role in animal nutrition, as it contributes to an acidic $\mathrm{pH}$ in the gastrointestinal tract, which inhibits pathogenic bacteria while favouring the occurrence of beneficial microbes. The use of this vitamin should mainly be recommended in pigs, which only synthetize it to a small degree as compared to other livestock animals (Lechowski, 2009). The antioxidant effect of vitamin $\mathrm{C}$ is particularly important, as it reacts with free radicals to transform them into less toxic compounds (Janda et al., 2015; Sroka et al., 2005). Ascorbic acid also acts on the immune system by stimulating the formation of certain immunoglobulins, especially IgM (Lauridsen and Jensen, 2005). It is important to administer vitamin $\mathrm{C}$ to piglets, especially in stress situations, which include weaning. It is also 
a potential source of protection against environmental oxidative stress and transport stress in pigs (Adenkola et al., 2009; Carr and Maggini, 2017).

The aim of the study was to assess the gut microbiota and selected haematological and biochemical parameters of the blood following supplementation of piglet feed with a probiotic and vitamin $\mathrm{C}$.

\section{Material and methods}

\section{Animals used in the experiment}

The research on animals was carried out with Ethics Committee approval (no. 22/2012).

The research was carried out on a pig farm in the Lublin Voivodeship, Poland. The pigs were kept in a closed cycle in a deep litter system and the herd consisted of 500 animals. The study was conducted on F1 Duroc $\times$ Pietrain and Pietrain $\times$ Duroc crossbreds (sow $\times$ boar). The piglets were under veterinary care throughout the rearing period and showed no disease symptoms. Sixty piglets were used in the study.

The piglets were weaned from their mothers at the age of 40 days, and the experiment was begun when they were 47 days old. The animals were of the same age and had similar body weight (16.00-16.90 kg). All piglets were fed complete compound feed produced on-farm, containing wheat (39.75\%), spring barley $(39.75 \%)$, rapeseed oil $(0.5 \%)$ and the commercial supplement mix 'Protamino piggi' from Sano $(20 \%)$. The feed did not contain either vitamin $\mathrm{C}$ or a probiotic. All piglets were fed the same feed ad libitum and had unrestricted access to water.

The piglets were divided into a control group (group C) and an experimental group (group E), with 30 piglets in each group. The piglets were kept in two pens group $\mathrm{E}$ in one and group $\mathrm{C}$ in other. The ratio of males to females was 1:1 in each group.

The animals in the control group (group C) received feed with no added probiotic and vitamin $\mathrm{C}$. The piglets in the experimental group (group E) were given a supplement containing a probiotic (Bacillus cereus $1 \times 10^{9} \mathrm{CFU} / \mathrm{kg}$ ) (Lohmann Animal Health, Grodzisk Mazowiecki, Poland) in the amount of $1.5 \mathrm{~g} /$ piglet/day and vitamin C (JFARM, Ostrołęka, Poland) in the amount of $300 \mathrm{mg} /$ piglet/day in a small portion of feed, before receiving their regular feed ration. The supplement was administered for 28 days.

Faeces and blood were collected from the animals from both groups at three different times: 1 ) day 0 , i.e. seven days after weaning, before administration of the probiotic and vitamin $C$; 2 ) day 28 , i.e. after 4 weeks of administration of the supplement; 3 ) day 35 , i.e. seven days after supplementation was discontinued.

\section{Bacteriological testing of faeces}

Faeces for bacteriological cultures were collected from the rectum of 20 animals from the experimental group and 20 from the control group. Quantitative and qualitative bacteriological tests of the faeces were performed according to Polish 
Standard PN-EN ISO 7218:2008. The total number of bacteria of the Enterobacteriaceae family was determined by plating diluted samples on VRBG agar (BTL, Łódź, Poland) according to Polish Standard PN-ISO 21528-2:2005. To prepare dilutions of the samples, $1 \mathrm{~g}$ of faeces was placed in $90 \mathrm{ml}$ of Ringer's solution and homogenized. A series of dilutions of the homogenate was made, from $10^{-2}$ to $10^{-7}$, by transferring $1 \mathrm{ml}$ of material to a tube containing $9 \mathrm{ml}$ of Ringer's solution. After plating onto nutrient agar, the Petri dishes were incubated at $37^{\circ} \mathrm{C}$ for 24 hours. To isolate pure bacterial cultures, a culture was grown on MacConkey agar (BTL, Łódź, Poland) and the colonies were counted following incubation. The number of Lactobacillus bacteria was determined by plating samples on MRS agar (BTL, Łódź, Poland) and incubating them at $37^{\circ} \mathrm{C}$ in aerostats (Oxoid, Basingstoke, United Kingdom) for 24-48 hours, after which the bacterial colonies were counted (PN-EN 15787:2009). The number of microbes is presented as decimal logarithms per $\mathrm{g}$ fresh weight of faeces in colony-forming units ( $\log \mathrm{CFU} / \mathrm{g})$. Bacteria of the family Enterobacteriaceae were identified to species by the microtube method using API 20 E tests (bio Merieux, Warsaw, Poland).

\section{Haematological and biochemical testing of blood}

Blood was taken from the anterior vena cava of 60 animals (30 piglets from each group). The blood samples $(4.9 \mathrm{ml})$ were collected into S-Monovette tubes (Sarstedt AG \& Co, Numbrecht, Germany) and tubes with K2 EDTA (Profilab Sc. Warsaw, Poland). A scil Vet abc Plus haematology analyser (HORIBA Medical, Montpellier, France) was used to determine selected haematological parameters, i.e.: erythrocyte count, haemoglobin concentration, haematocrit, leukocyte count, and percentages of neutrophils and lymphocytes.

The concentrations of triacylglycerols, total cholesterol, and HDL and LDL cholesterol were determined using a BS-130 automatic biochemistry analyser (Mindray, Shanghai, China).

\section{Statistical analysis}

The results of the tests are presented in tables. The levels of the analysed parameters in each group were compared by one-way analysis of variance and Student's t-test, using SPSS 12.0 PL statistics software.

\section{Results}

In the faeces of piglets receiving the probiotic and vitamin $\mathrm{C}$ (group $\mathrm{E}$ ), there was a significant reduction $(\mathrm{P}<0.01)$ in the number of Enterobacteriacae bacteria between faeces sampled on days 0 and 28 (by 1.28 log units), and a significant increase $(\mathrm{P}<0.01)$ between days 28 and 35 (by $1.07 \log$ units) (Table 1). In the faeces of the piglets in the control group (group $\mathrm{C}$ ), there was a significant decrease $(\mathrm{P}<0.01)$ in the bacterial count between days 0 and 28 of the study (by $0.95 \log$ units) and a significant increase $(\mathrm{P}<0.01)$ between days 28 and 35 (by 1.57 units). At 35 days 
the number of these bacteria was also 0.62 units higher $(\mathrm{P}<0.01)$ than the initial level (day 0 ).

Table 1. Mean total number of bacteria $(\log \mathrm{CFU} / \mathrm{g})$ in the faeces of piglets receiving the probiotic with vitamin C

\begin{tabular}{|c|c|c|c|c|c|c|}
\hline \multirow{2}{*}{ Taxonomy } & \multirow{2}{*}{ Group } & \multicolumn{3}{|c|}{ Sampling day } & \multirow{2}{*}{ Total } & \multirow{2}{*}{ SEM } \\
\hline & & 0 days & 28 days & 35 days & & \\
\hline \multirow{2}{*}{$\begin{array}{l}\text { Family } \\
\text { Enterobacteriaceae (E) }\end{array}$} & $\mathrm{C}$ & $7.43 \mathrm{~B}$ & $6.48 A^{*}$ & $8.05 \mathrm{C}^{* *}$ & 7.01 & \multirow[t]{2}{*}{0.120} \\
\hline & E & $7.24 \mathrm{~B}$ & $5.96 \mathrm{~A}^{*}$ & $7.03 \mathrm{~B}^{* *}$ & 7.14 & \\
\hline \multirow{2}{*}{$\begin{array}{l}\text { Genus Lactobacillus } \\
\text { (L) }\end{array}$} & $\mathrm{C}$ & $8.53 \mathrm{~B}$ & $8.70 \mathrm{~B}^{* *}$ & $7.68 \mathrm{~A}^{* *}$ & $8.35 * *$ & \multirow[t]{2}{*}{0.120} \\
\hline & E & $8.93 \mathrm{a}$ & $9.42 b^{* *}$ & $8.98 \mathrm{a}^{* *}$ & $9.11 * *$ & \\
\hline
\end{tabular}

$\mathrm{A}, \mathrm{B}, \mathrm{C}-$ values with different letters in rows differ significantly at $\mathrm{P} \leq 0.01$.

$\mathrm{a}, \mathrm{b}-$ values with different letters in rows differ significantly at $\mathrm{P} \leq 0.05$.

** - values in columns differ significantly at $\mathrm{P} \leq 0.01$.

* - values in columns differ significantly at $\mathrm{P} \leq 0.05$.

$\mathrm{C}-$ control group.

$\mathrm{E}$ - experimental group.

The feed supplement given to the piglets caused a significant $(\mathrm{P}<0.05)$ decrease in the total number of bacteria of the family Enterobacteriaceae (by $0.52 \log$ units) in the faeces of piglets from the experimental group as compared to the control after 28 days of administration. The number of these bacteria decreased significantly $(\mathrm{P}<0.01)$, by $1.02 \log$ units, seven days after supplementation was discontinued.

There was a significant $(\mathrm{P}<0.01)$ increase in the total number of Lactobacillus bacteria relative to the control group immediately after supplementation, by $0.72 \log$ units, and a significant $(\mathrm{P}<0.01)$ increase of $1.3 \log$ units seven days after it was completed (Table 1). In the experimental group, a significant increase in the number of these bacteria $(\mathrm{P}<0.05)$ was found between faeces sampled at 0 and 28 days, by 0.49 $\log$ units, while a significant $(\mathrm{P}<0.05)$ decrease of $0.44 \log$ units was demonstrated between faeces sampled at 28 and 35 days. In the control group, a significant reduction $(\mathrm{P}<0.01)$ in the number of Lactobacillus bacteria was noted between days 0 and 35 and between days 28 and 35 of the study, by 0.85 and 1.02 units, respectively.

In the qualitative tests of piglet faeces, E. coli bacteria were predominant over other microorganisms (Figures 1-3). In faeces sampled at 28 days, a slight decrease in the percentage of these microorganisms was noted in the experimental group (group E). However, seven days after the supplement was discontinued, this percentage had increased (Figures 2-3). Before the start of administration of the probiotic with vitamin C (group E), Salmonella choleraesuis was found in the faeces of piglets in both groups (Figure 1). However, these bacteria were not detected on days 28 and 35 . The remaining microorganisms isolated were part of the physiological gut microbiota and accounted for only a small percentage.

The probiotic and vitamin $\mathrm{C}$ supplementation resulted in a statistically significant increase $(\mathrm{P}<0.01)$ in the erythrocyte count and haemoglobin level and a significant increase $(\mathrm{P}<0.05)$ in the haematocrit in the blood of piglets sampled at 28 days, as compared with the control (Table 2). 


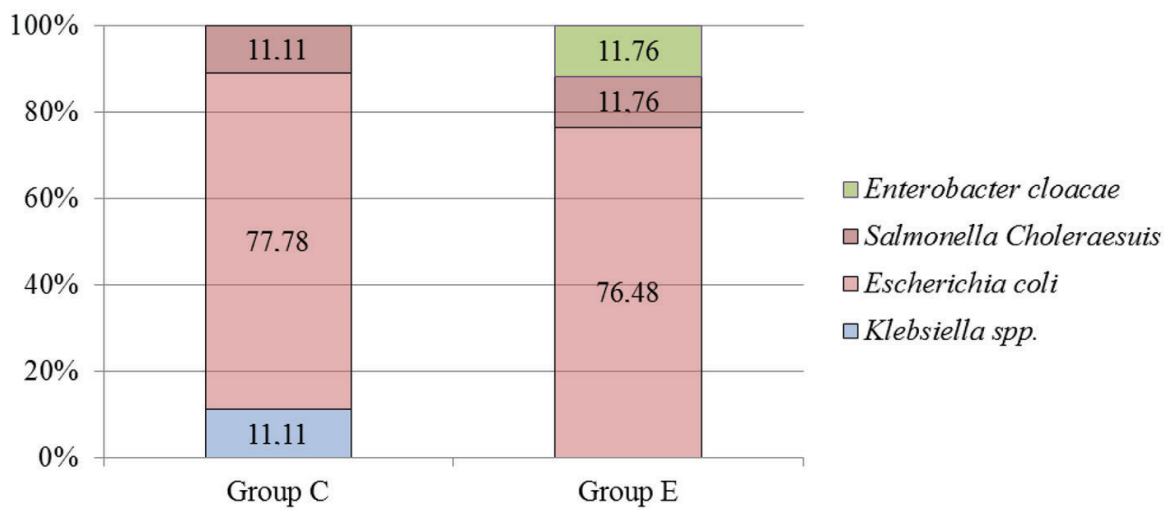

Figure 1. Identified bacteria of the family Enterobacteriaceae (in \%) in the faeces of piglets seven days after weaning, before administration of the supplement (day 0 )

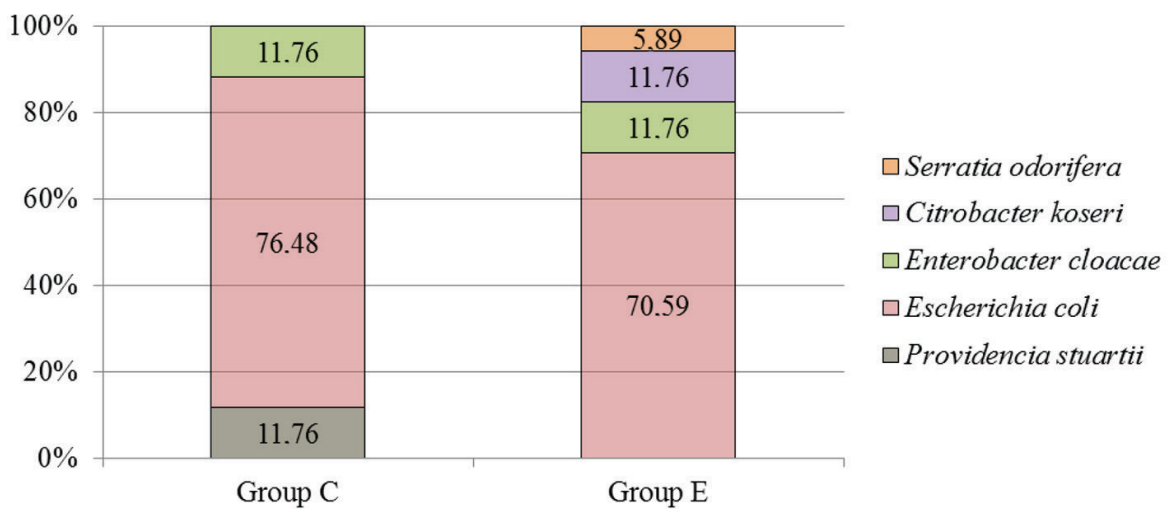

Figure 2. Identified bacteria of the family Enterobacteriaceae (in \%) in the faeces of piglets after four weeks of administration of the supplement (day 28)

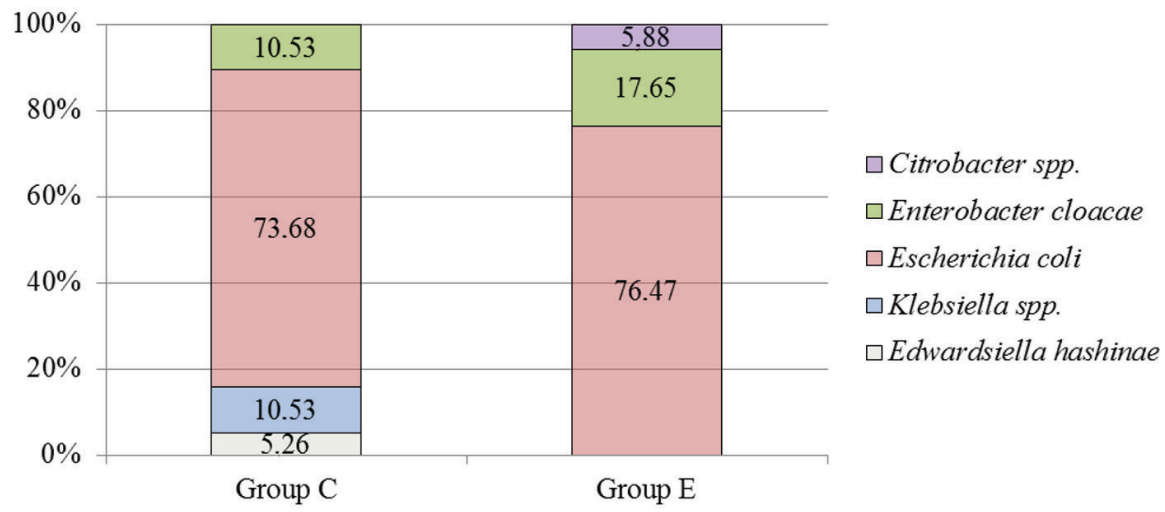

Figure 3. Identified bacteria of the family Enterobacteriaceae (in \%) in the faeces of piglets seven days after supplementation was discontinued (day 35) 
Table 2. Haematological parameters of the blood of piglets

\begin{tabular}{|c|c|c|c|c|c|c|}
\hline \multirow{2}{*}{ Parameter } & \multirow{2}{*}{ Group } & \multicolumn{3}{|c|}{ Sampling day } & \multirow{2}{*}{ Total } & \multirow{2}{*}{ SEM } \\
\hline & & 0 days & 28 days & 35 days & & \\
\hline \multirow[t]{2}{*}{ Erythrocytes $\left(10^{12} / \mathrm{L}\right)$} & $\mathrm{C}$ & 6.68 & $6.59 * *$ & 7.07 & $6.80 *$ & 0.120 \\
\hline & $\mathrm{E}$ & 6.98 & $7.67 * *$ & 7.80 & $7.48 *$ & \\
\hline \multirow[t]{2}{*}{ Haemoglobin $(\mathrm{Mmol} / \mathrm{L})$} & $\mathrm{C}$ & 7.10 & $6.97 * *$ & $7.07^{*}$ & $7.05 * *$ & 0.119 \\
\hline & $\mathrm{E}$ & 7.45 & $8.07 * *$ & $8.15^{*}$ & $7.89 * *$ & \\
\hline \multirow[t]{2}{*}{ Haematocrit (L/L) } & $\mathrm{C}$ & 0.36 & $0.37 *$ & 0.39 & $0.37 * *$ & 0.045 \\
\hline & $\mathrm{E}$ & 0.38 & $0.42 *$ & 0.43 & $0.42 * *$ & \\
\hline \multirow[t]{2}{*}{ Leukocytes $\left(10^{9} / \mathrm{L}\right)$} & $\mathrm{C}$ & 22.77 & 18.80 & 20.81 & 20.79 & 1.013 \\
\hline & $\mathrm{E}$ & 24.86 & 23.31 & 20.62 & 22.93 & \\
\hline \multirow[t]{2}{*}{ Neutrophils (\%) } & $\mathrm{C}$ & 28.13 & 27.84 & 25.87 & 27.28 & 0.813 \\
\hline & $\mathrm{E}$ & 26.96 & 30.73 & 29.35 & 29.01 & \\
\hline \multirow[t]{2}{*}{ Lymphocytes (\%) } & $\mathrm{C}$ & 65.02 & 63.18 & 61.80 & 63.24 & 1.434 \\
\hline & $\mathrm{E}$ & 69.75 & 69.50 & 64.74 & 68.26 & \\
\hline
\end{tabular}

** - values in columns differ significantly at $\mathrm{P} \leq 0.01$.

* - values in columns differ significantly at $\mathrm{P} \leq 0.05$.

$\mathrm{C}$ and $\mathrm{E}-$ as in Table 1.

Administration of the supplement caused no significant changes in leukocyte parameters $(\mathrm{P}>0.05)$.

The use of the probiotic and vitamin $\mathrm{C}$ in the diet significantly reduced $(\mathrm{P}<0.05)$ the concentration of triacylglycerols, total cholesterol and LDL cholesterol in the blood relative to the control group immediately after supplementation was discontinued (Table 3).

Table 3. Mean values of biochemical parameters in the blood of piglets

\begin{tabular}{|c|c|c|c|c|c|c|}
\hline \multirow{2}{*}{ Parameter } & \multirow{2}{*}{ Group } & \multicolumn{3}{|c|}{ Sampling day } & \multirow{2}{*}{ Total } & \multirow{2}{*}{ SEM } \\
\hline & & 0 days & 28 days & 35 days & & \\
\hline \multirow{2}{*}{$\begin{array}{l}\text { TG } \\
(\mathrm{Mmol} / \mathrm{L})\end{array}$} & $\mathrm{C}$ & 0.45 & $0.42 *$ & 0.46 & $0.44 *$ & \multirow[t]{2}{*}{0.017} \\
\hline & $\mathrm{E}$ & 0.43 & $0.31 *$ & 0.41 & $0.38^{*}$ & \\
\hline \multirow{2}{*}{$\begin{array}{l}\mathrm{CHOL} \\
(\mathrm{Mmol} / \mathrm{L})\end{array}$} & $\mathrm{C}$ & 2.58 & $2.82 *$ & 2.55 & $2.65^{*}$ & \multirow[t]{2}{*}{0.061} \\
\hline & E & $2.62 \mathrm{~B}$ & $2.06 \mathrm{~A}^{*}$ & 2.24 & $2.31 *$ & \\
\hline \multirow{2}{*}{$\begin{array}{l}\mathrm{CHOL}_{\mathrm{HDL}} \\
(\mathrm{Mmol} / \mathrm{L})\end{array}$} & $\mathrm{C}$ & 0.98 & $1.09 *$ & 0.97 & 1.01 & \multirow[t]{2}{*}{0.031} \\
\hline & $\mathrm{E}$ & $1.04 \mathrm{~b}$ & $0.84 \mathrm{a}^{*}$ & 0.93 & 0.94 & \\
\hline \multirow{2}{*}{$\begin{array}{l}\mathrm{CHOL}_{\mathrm{LDL}} \\
(\mathrm{Mmol} / \mathrm{L})\end{array}$} & $\mathrm{C}$ & 1.40 & $1.54^{*}$ & 1.37 & 1.44 & \multirow[t]{2}{*}{0.061} \\
\hline & E & $1.43 \mathrm{~b}$ & $1.08^{\mathrm{a} *}$ & $1.12 \mathrm{a}$ & 1.21 & \\
\hline
\end{tabular}

$\mathrm{A}, \mathrm{B}, \mathrm{C}-$ values with different letters in rows differ significantly at $\mathrm{P} \leq 0.01$.

$a, b-$ values with different letters in rows differ significantly at $\mathrm{P} \leq 0.05$.

* - values in columns differ significantly at $\mathrm{P}<0.05$.

TG - triacylglycerols

CHOL - total cholesterol.

$\mathrm{CHOL}_{\mathrm{LDL}}-\mathrm{LDL}$ cholesterol.

$\mathrm{CHOL}_{\mathrm{HDL}}$ - HDL cholesterol.

$\mathrm{C}$ and $\mathrm{E}-$ as in Table 1. 


\section{Discussion}

We have confirmed that the inclusion of a probiotic (Bacillus cereus) combined with vitamin $\mathrm{C}$ in the diet may have positive effects on some indicators of intestinal health, such as a significant decrease in the number of bacteria of the family Enterobacteriaceae and a significant increase in the number of Lactobacillus bacteria in the faeces of piglets.

A beneficial effect was probably exerted by the action of the probiotic enhanced by vitamin $\mathrm{C}$ as an acidifier. Administration of vitamin $\mathrm{C}$ to sows for three and six weeks has also resulted in a significant $(\mathrm{P}<0.05)$ decrease in the number of these bacteria in their faeces (Trawińska et al., 2012). Similar results have been obtained by Jadamus et al. (2002), who determined the number of Enterobacteriaceae bacteria in the faeces of piglets following feed supplementation with Bacillus cereus var. toyoi. A beneficial effect has also been obtained in fattening pigs using a feed supplement containing a strain of Pediococcus acidilactici, which resulted in a decrease in the number of Enterobacteriaceae bacteria and an increase in lactic acid bacteria (Rekiel and Gajewska, 2006). The reduction in the number of harmful bacteria from the Enterobacteriaceae family may be due to competition between probiotic strains and pathogenic microorganisms for nutrients and receptor sites, known as competitive exclusion (Liao and Nyachoti, 2017; Nowak et al., 2010). Substances produced by strains of bacteria of the genus Bacillus, including bacteriocins (e.g. cerein and subtilin) with confirmed bactericidal and bacteriostatic properties, as well as antibiotics such as surfactin, bacilysin and subtilisin, are also antagonistic to pathogenic microorganisms (Elshaghabee et al., 2017). On the other hand, enzymes, vitamins and peptides produced outside the cell stimulate the growth of commensal and beneficial gut flora and influence its composition, helping to maintain homeostasis in the gut. This is confirmed by our own research.

The feed additive used in our study significantly increased the number of Lactobacillus bacteria in the faeces. A similar effect has been reported by Napiórkowska et al. (2014), who used a preparation containing an Enterococcus faecium strain in the diet of piglets. The use of a preparation containing bacterial strains of the genus Lactobacillus in piglets has also been found to increase their resistance to infections caused by pathogenic E. coli bacteria two weeks after weaning (Huang et al., 2004). The administration of probiotic and prebiotic preparations has been shown to have a favourable effect on the intestinal microbial population in piglets by increasing the number of beneficial microbes and reducing the number of pathogenic ones (Mojka, 2014; Shim et al., 2005). Probiotic substances, by exhibiting the ability to adhere to the intestinal epithelium, protect the intestinal wall against harmful agents forming a biofilm and stimulate immunoglobulin production and phagocytosis (Mojka, 2014).

The qualitative bacteriological testing of the faeces showed a slight decrease in the percentage of $E$. coli bacteria after 28-day administration of the probiotic and vitamin $C$, but seven days after the supplement was discontinued, a percentage increase in these bacteria was observed. Thirty-day administration of a probiotic containing Enterococcus faecium to pigs has been found to significantly reduce the number of E. coli and Clostridium perfringens in their faeces (Pospišková et al., 2013). In addi- 
tion, supplementation with probiotics or xylooligosaccharides has been found to reduce the number of $E$. coli bacteria in the faeces of weaned piglets (Liu et al., 2018).

Prior to the start of administration of the probiotic and vitamin $\mathrm{C}$, pathogenic Salmonella choleraesuis were found in the faeces of animals from both groups, although the piglets showed no disease symptoms. However, these bacteria were not detected in subsequent samples. Similar results have been obtained by Casey et al. (2007), who showed that the use of a mixture of probiotics from the genus Lactobacillus caused a reduction in Salmonella typhimurium in pigs.

Many probiotic bacteria, including Bacillus sp., ferment carbohydrates to produce organic acids thereby dropping the luminal $\mathrm{pH}$ to a level that harmful bacteria cannot tolerate (Liao and Nyachoti, 2017). A decrease in gut $\mathrm{pH}$ by vitamin $\mathrm{C}$ may additionally offset the low secretion of hydrochloric acid in the stomach of weanling piglets.

The results confirm the beneficial effect of supplementation with vitamin $\mathrm{C}$ together with a probiotic on the erythrocyte parameters of the blood of piglets. Similar results have been reported by Friedrich (1988), who found that the inclusion of vitamin $\mathrm{C}$ alone in the diet of piglets increased the erythrocyte count and haemoglobin and haematocrit levels in the blood. The increase in the number of erythrocytes is probably linked to the involvement of vitamin $\mathrm{C}$ in erythropoiesis. In addition, it is present in significant amounts in red blood cells. Other researchers (de Rodas et al., 1998), however, have found that the addition of vitamin $\mathrm{C}$ had no effect on haemoglobin and haematocrit levels in weaned piglets. Kunavue and Lien (2012), after administering a probiotic to pigs together with fulvic acid, found no effect of this additive on red blood cell parameters, but noted a beneficial effect on immunity. Our research found no significant differences in leukocyte parameters. In contrast, Szakacs et al. (2016) reported that a probiotic increased the leukocyte count in pig blood, thereby stimulating the immune system.

The use of the supplement in the diet of weaned piglets also caused a significant reduction in lipid profile parameters. This was probably due to the addition of vitamin $\mathrm{C}$, which as an antioxidant may prevent lipid peroxidation (Maćkowiak and Troliński, 2007). Ascorbic acid, by participating in the hydroxylation of cholesterol to bile acids, reduces its level in the blood and tissues, thereby preventing atherosclerosis (Das et al., 2006). According to some authors (Pereira and Gibson, 2002; Pătrascanu et al., 2011), the presence of a probiotic in a feed additive has also reduced total and LDL cholesterol. A decrease in cholesterol content in the blood vessels of animals and humans is made possible by the assimilation and degradation processes taking place. Most of the cholesterol metabolized in the body is excreted in faeces in the form of bile acids. Probiotic substances probably increase the excretion of cholesterol in the faeces by inhibiting the formation of easily digested fat micelles (Mojka, 2014).

\section{Conclusions}

The probiotic in combination with vitamin $\mathrm{C}$ added to the diet of the piglets had a beneficial effect on the gut microbiota, causing a decrease in the number of bacteria of the family Enterobacteriaceae while increasing the number of lactobacilli. This 
was probably due to the effect of vitamin $\mathrm{C}$ as a feed additive acidifying the gut microflora and inhibiting the growth of pathogenic bacteria, as well as to the effect of the probiotic protecting the intestinal wall against the penetration of pathogenic microbes. The use of this supplement in the diet also had a beneficial effect on red blood cell and lipid parameters of the blood.

\section{References}

A d e n k o la A.Y., A y o J.O., S a c k e y A.K.B., A d e 1 a i y e A.B. (2009). Haematological and serum biochemical changes in pig administered with ascorbic acid and transported by road for four hours during the harmattan season. J. Cell Anim. Biol., 3: 21-28.

Asml A., Agazzi A., Invernizzi G., Bontempo V., Savoini G. (2015). The beneficial role of probiotics in monogastrics animal nutrition and health. J. Dairy Vet. Anim. Res., 2: $116-132$.

C arr A.C., M a g g in i S. (2017). Vitamin C and immune function. Nutrients, 9: 1211-1220.

C a sey P.G., Gardiner G.E., C a se y G., B rad shaw B., Law lor P.G., Ly n ch P.B., Le on ard F.C., Stant on C., R os s R.P., F itzgerald G.F., Hill C. (2007). A five-strain probiotic combination reduces pathogen shedding and alleviates disease signs in pigs challenged with Salmonella enterica serovar Typhimurium. Appl. Environ. Microbiol., 73: 1858-1863.

Corcionivoschi N., Drince anu D., Pop I.M., Stack D., Stef L., Julean C., Bourke B. (2010). The effect of probiotics on animal health. Anim. Sci. Biotechnol., 43: 35-41.

Dalmini Z.C., Lang a R.L.S., A iy e goro O.A., Ok oh A.I. (2017). Effects of probiotics on growth performance, blood parameters and antibody stimulation in piglets. S. Afr. J. Anim. Sci., 47: 766-775.

D a s S., S n eh lat a R.R.., D a s N. S riv a s t a v a L.M. (2006). Effect of ascorbic acid on prevention of hypercholesterolemia induced atherosclerosis. Mol. Cell. Biochem., 285: 143-147.

E 1 sh a ghabe e F.M.F., Rok an a N., Gulhane R.D., Sharma C., P anwar H. (2017). Bacillus as potential probiotics: status, concerns, and future perspectives. Front. Microbiol., 8: 1490; doi: 10.3389/fmicb.2017.01490.

Fri e d r i c h W. (1988). Vitamins. Gruyter, Berlin, New York.

Gi a n g H.H., Viet T.Q., O gle B., Lind be d e rg J.E (2012). Growth performance, digestibility, gut environment and health status in weaned piglets fed a diet supplemented with a complex of lactic acid bacteria alone or in combination with Bacillus subtilis and Saccharomyces boulardii. Livest. Sci., 143: 132-141.

H u a g C., Q i a o S., Li D., P i a X., R en J. (2004). Effects of Lactobacilli on the performance, diarrhea incidence, VFA concentration and gastrointestinal microbial flora of weaning pigs. AsianAustralas. J. Anim. Sci., 17: 401-409.

J a d a m u s A., Wahj en W., S chä fer K., S i m on O. (2002). Influence of the probiotic strain $B a-$ cillus cereus var. toyoi on the development of enterobacterial growth and on selected parameters of bacterial metabolism in digesta samples of piglets. J. Anim. Physiol. Anim. Nutr., 86: 42-54.

J and a K., K a s przak M., Wo 1 s k a J. (2015). Vitamin C - structure, properties, occurrence and functions (in Polish). Pom. J. Life Sci., 61: 419-425.

Janik A., Koska M., Paluch U., Pieszka M., B arowicz T. (2006). Probiotics in feeding piglets (in Polish). Wiad. Zoot., 1: 3-9.

$\mathrm{K}$ u $\mathrm{n}$ a v u e N., L i e n T.F. (2012). Effects of fulvic acid and probiotic on growth performance, nutrient digestibility, blood parameters and immunity of pigs. J. Anim. Sci. Adv., 2: 711-721.

L a u rids en C., J e n s e n S.K. (2005). Influence of supplementation of all-rac-alpha-tocopheryl acetate preweaning and vitamin $\mathrm{C}$ postweaning on alphatocopherol and immune responses in piglets. J. Anim. Sci., 83: 1274-1286.

L e chowski J. (2009). Evaluation the effect of dietary ascorbic acid supplement on the performance parameters of young gilts and insemination boars as well as physiological and chemical properties of fattener's meat (in Polish). Rozpr. Hab., UP Lublin, 334: 5-61 
Lee S.H., Ingale S.L., Kim J.S., Kim K.H., Lokhande A., Kim E.K., Kwon I.K., K i m Y.H., C h a e J. (2014). Effects of dietary supplementation with Bacillus subtilis LS 1-2 fermentation biomass on growth performance, nutrient digestibility, cecal microbiota and intestinal morphology of weanling pig. Anim. Feed Sci. Technol., 188: 102-110.

L i a o S.F., N y a c h ot i M. (2017). Using probiotics to improve swine gut health and nutrient utilisation. Anim. Nutrition, 3, 331-343.

Li u J.B., C a o S.C., Li u J., Xie Y.N., Zhang H.F. (2018). Effect of probiotics and xylo-oligosaccharide digestibility, intestinal health and noxious gas emission in weanling pigs. AJAS, 31: 1660-1669.

Maćk owiak K., Trolińs ki L. (2007). Contemporary view on the role of vitamin C in human physiology and pathology (in Polish). Nowiny Lek., 4: 349-356.

M о j ka K. (2014). Probiotics, prebiotics and synbiotics - characteristics and functions (in Polish). Probl. Hig. Epidemiol., 95: 541-549.

Napiórkowska B., Dobrow ols ka Z., Wi ęcek J., Gajews k a J., R e ki el A. (2014). Effect of a probiotic preparation on daily weight, gain, survival rate and composition of faecal microflora in piglets (in Polish). Rocz. Nauk. PTZ, 10: 57-68.

Nowak A., Śliżew s k a K., Li budzis z Z. (2010). Probiotics - history and mechanisms of their effect (in Polish). Zywn.-Nauk. Technol. Ja., 4: 5-19.

Pătra s c a nu M.E., V lăg i o i u R.M.. P a vel C.I., Răd o i I., V lăgi o iu C. (2011). The impact of probiotic administration on clinical hematological and biochemical parameters in pregnant sows. Bull. UASVM Vet. Med., 68: 240-247.

P e r e ir a D.I., Gi b s on G.R. (2002). Effects of consumption of probioticts and prebiotics on serum lipid levels in humans. Crit. Rev. Biochem. Mol. Biol., 37: 259-281.

Polish Norm PN-EN ISO 7218:2008. Microbiology of food and animal feeding stuffs. General requirements and guidance for microbial examinations.

Polish Norm PN-EN 15787:2009. Animal feeding stuffs. Isolation and numeration of Lactobacillus spp.

Polish Norm PN-ISO 21528-2:2005. Microbiology of food and animal feeding stuffs. Horizontal method for the detection and enumeration of Enterobacteriaceae, part 2: colony-count method.

Pospišková P., Zorniková G., Kolárová M., S lá d e k Z., K o m prda T., G e rš i ová J. (2013). Effect of probiotics in the pig nutrition on the pathogenic bacteria counts in the gut. Acta Univ. Agric. Silvic. Mendel. Brun., 205: 1839-1843.

Rekiel A., Gajewska J. (2006). Changes in the intestinal microflora of fatteners as affected by selected nutritional factors (in Polish). Med. Weter., 62: 925-930.

de Rodas B.Z., Maxwell C.V., Davis M.E., Mandali S., Broekman E., Stoeck e r B.J. (1998). L-ascorbyl-2-polyphosphate as a vitamin C source for segregated and conventionally weaned pigs. J. Anim. Sci., 76: 1636-1643.

S hengfa F.L., Ny a ch ot i M. (2017). Using probiotics to improve swine gut health and nutrient utilization. Animal Nutr., 3: 331-343.

S h i m S.B., Vers te ge n M.W., K i m I.H., K w on O.S., Verd on k J.M. (2005). Effects of feeding antibiotic-free creep feed supplemented with oligofructose, probiotics or synbiotics to suckling piglets increases the preweaning weight gain and composition of intestinal microbiota. Arch. Anim. Nutr., 59: 419-427.

S rok a Z., Gamian A., C is ow ski W. (2005). Low-molecular antioxidant compounds of natural origin (in Polish). Post. Hig. Med. Dośw., 59: 34-41.

S zak a c s A. R., M a te i S., S te fănut L., Moni Z., M a cri A. (2016). Effects of pre and probiotic on growth performance and haematological parameters in pigs. Bull. UASVM Vet. Med., 73: $265-300$.

Śliżewska K., B i ernasiak J., Libudzisz Z. (2006). Probiotics as alternative for antibiotics (in Polish). Zesz. Nauk. Politechniki Łódzkiej. Chemia Spoż. i Biotechnol., 984: 79-91.

Trawińska B., L e chows ki J., P ol on is A., Kow a le c zko M. (2012). Effect of feed supplemented with vitamin $\mathrm{C}$ on microbial flora of swine faeces and blood morphology. Bull. Vet. Inst. Pulavy, 56: 171-175. 